\title{
Granite is an Effective Helium Source Rock: Insights from the Helium Generation and Release Characteristics in Granites from the North Qinling Orogen, China
}

\author{
ZHANG Wen ${ }^{1}$, LI Yuhong ${ }^{2,}$, ZHAO Fenghua ${ }^{3}$, ZHOU Zheng ${ }^{4}$, HAN Wei ${ }^{2}$, ZHOU Junlin² and ZHANG Qiao ${ }^{2}$ \\ ${ }^{1}$ Key Laboratory of Deep-Earth Dynamics of Ministry of Natural Resources, Laboratory of Isotope Thermochronology, \\ Institute of Geology, Chinese Academy of Geological Sciences, Beijing, 100037, China \\ ${ }^{2}$ Xi'an Center, China Geological Survey, Xi'an, 710054, China \\ ${ }^{3}$ College of Geoscience and Surveying Engineering, China University of Mining and Technology, Beijing, 100083, China \\ ${ }^{4}$ Lancaster Environment Centre, Lancaster University, Lancaster, LA1 4YQ, UK
}

\begin{abstract}
Global helium (He) shortage is a challenging problem; however, the types of helium source rock and the mechanisms of He generation and release therein remain still poorly understood. In this study, in order to evaluate the potential of granite as an effective helium source rock, we collected granitic samples from the North Qinling Orogen, Central China, in the south of the helium-rich Weihe Basin. The helium generation and release behaviors in granite were studied through analysis of $\mathrm{U}$ and Th concentrations, EMPA images, and $\mathrm{He}$ and Ar concentrations and isotopic ratios extracted by crushing and stepwise heating. The results indicate that Ar has a better retention and a lower mobility than $\mathrm{He} .{ }^{3} \mathrm{He} /{ }^{4} \mathrm{He}$ ratios released by crushing and stepwise heating are $0.016-0.056 R_{A}$ and $0.003-0.572 R_{A}$, respectively, where $R_{A}$ is the atmospheric ${ }^{3} \mathrm{He} /{ }^{4} \mathrm{He}$ of $1.4 \times 10^{-6}$, reflecting a crustal and radiogenic source. Helium concentrations extracted by the two ways are $0.13-0.95 \mathrm{ucm}^{3} \mathrm{STP} / \mathrm{g}$ and $7.82-115.62 \mathrm{ucm}^{3} \mathrm{STP} / \mathrm{g}$, respectively, suggesting that matrix-sited He accounts for more than $98 \%$ of total helium preserved in granite. In addition, the total generated He amounts in granites are calculated based on the measured $U$ and Th concentrations in granitic samples. Dividing the preserved He quantities by the generated He amounts, it turned out that less than $10 \%$ of He produced since the formation of the granite is preserved in the rock over geological time, suggesting that more than $90 \%$ generated He can be transferred to the Weihe Basin. Temperature and fracture are the two critical factors controlling He release. Based on the relationship between He diffusivity of granites and temperature and the $\mathrm{He}$ closure temperatures of a variety of $\mathrm{U}$ - and Th-rich minerals $\left(27-250^{\circ} \mathrm{C}\right)$, we estimate that $\mathrm{He}$ can be partially released out of granite at the depths $<400 \mathrm{~m}$ and totally released at the depths $>7800 \mathrm{~m}$. Fractures provide effective transfer of free He from deep source rocks to shallow reservoirs. Finally, a model on granite as an effective helium source rock is established. We suggest exploring He resources in hydrocarbon basins with granitic basement (or adjacent to granite bodies), high geothermal field, and young active fractures.
\end{abstract}

Key words: granite, helium source rock, helium diffusivity, crushing, stepwise heating

E-mail: wenzhangcn@ outlook.com

\section{Introduction}

Helium is a strategic resource that has been widely used in military, nuclear industry, cryogenic superconductor, and scientific research (Cai et al., 2010). It is often extracted as a by-product of natural gas processing or during the production of liquefied natural gas (LNG). At present, the economically recoverable He resources in the world have low ${ }^{3} \mathrm{He} /{ }^{4} \mathrm{He}$ ratios, suggesting that most of them were derived from the radioactive decay of $U$ and Th (Ballentine and Lollar, 2002). At the end of 2006, He resources and reserves of the world were estimated to be about 51.9 and 7.4 billion cubic meters, respectively. The annual He demand is approximately 170 million cubic meters (Hamak, 2016). The He reserve and supply of the USA both account for more than $50 \%$ of the global amounts. At present, the world supply cannot meet the He demand, causing a "Liquid Helium Crisis" (Simon et al., 2016) and a "MRI Helium Crisis" (Mahesh and Barker, 2016). This issue has attracted broad attention on He reserves in many countries including China (Li et al., 2011; Zhang et al., 2019a; Zhang et al., 2019b; Tao et al., 2019), the USA (Brown, 2010), Qatar (Flower, 2012), Algeria (Reinoehl, 2012), Russia (Yakutseni V.P., 2014) and Tanzania (Danabalan et al., 2016; Ballentine et al., 2017).

China is a He-poor country, and He has been mainly exploited from a small gas field in the Sichuan Basin for more than 50 years (Wang et al., 2011). In recent years, extensive helium resources have been discovered from geothermal wells in the Weihe Basin, Central China (Liu et al., 2009; Li et al, 2011, 2015, 2016; Han et al., 2014; Zhang, 2015; Zhang et al., 2018; Zhang et al., 2019a; Zhang, 2019). The average He concentration in 101 wells is $1.50 \%$ and the maximum value is up to $9.23 \%$, being the highest reported He concentration in China (Zhang 
et al., 2018). The He isotopic ratios $\left({ }^{3} \mathrm{He} /{ }^{4} \mathrm{He}=2.2-78 \times 10^{-8}\right.$, Zhang, 2015) reflect a primarily crustal and radiogenic source except for a few outliers. The correct estimation and economic recovery of He resources in the Weihe Basin are vital to the He market in China and around the world.

The urgent demand and uneven distribution of He around the world leads to an interesting question: where does the He come from? By analyzing the geologic settings of other He-rich gas fields, such as the Hugoton-Panhandle giant gas field in the USA (Ballentine and Lollar, 2002), the Weiyuan gas field in China (Zhang et al., 2015) and the Hassi R'Mel gas fields in Algeria (Sabaou, et al., 2009), it has been suggested that the accumulation of $\mathrm{He}$ is closely related to the granitoid basement or intrusions (Fig. 1). However, although the generation and release / preservation of He in sedimentary rocks and $\mathrm{U}$ - and Th-rich minerals have been studied in the field of groundwater modeling (Fourré et al., 2011; Tolstikhin et al., 2011) and U-Th-He dating (Wolf et al., 1998; Reiners, et al., 2002), little research on the system of He generation and release in granite has been carried out (Hussain, 1997).

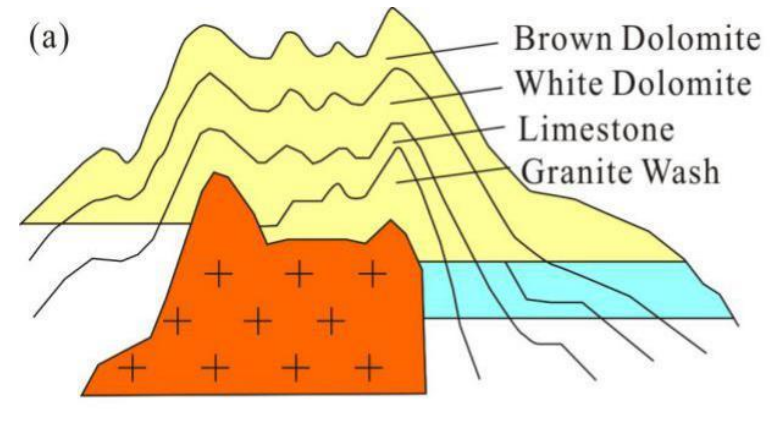

$$
\text { (c) Well } \mathrm{Hr}-4
$$
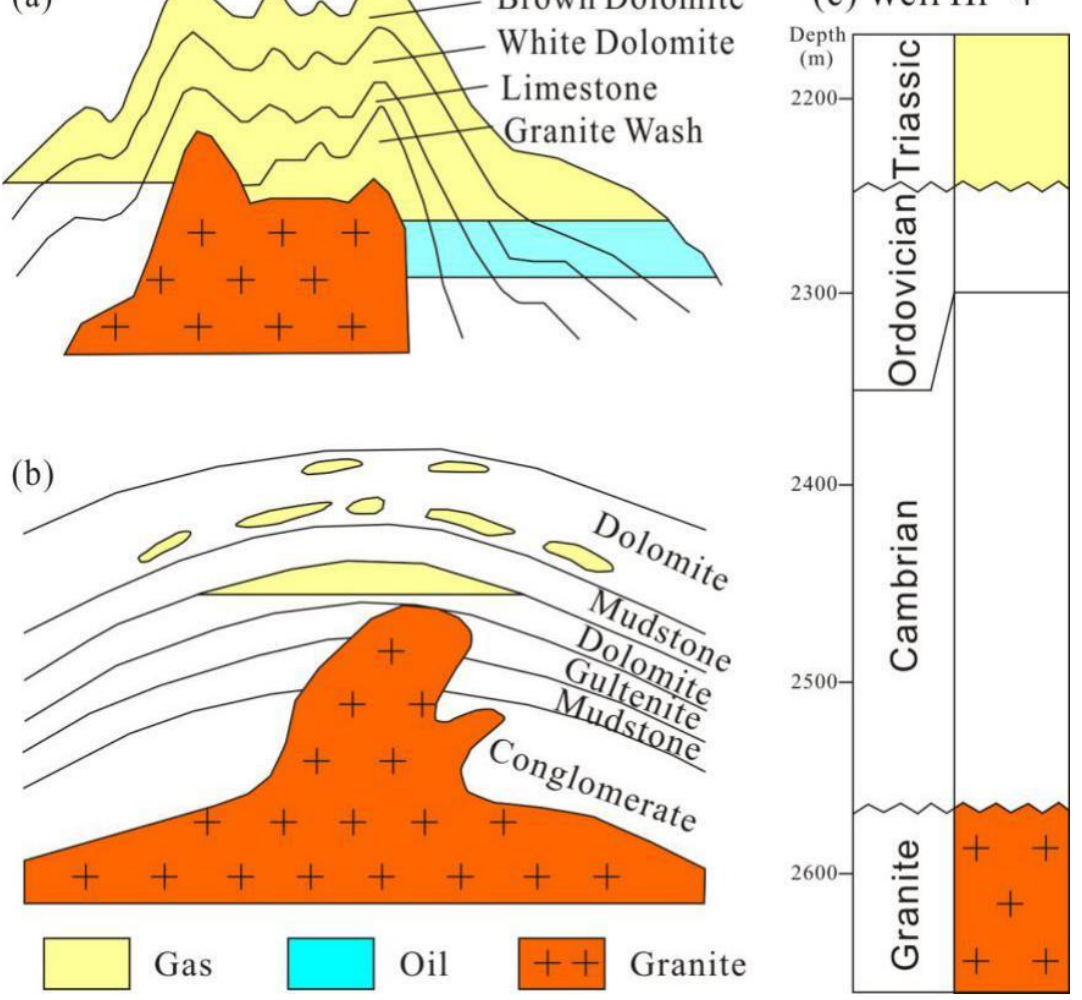

Fig. 1. Correlation between He-rich gas fields and granite.

(a) Hugoton-Panhandle gas field, USA (after Ballentine and Lollar, 2002); (b) Weiyuan gas field, China (after Zhang et al., 2015); (c) Hassi R'Mel, Algeria (after Sabaou et al., 2009).

The term 'helium source rock' has been used by Burwash and Cumming (1974) and Brown (2010) but without clear definition. In this study, as analogue to the definition of hydrocarbon source rock, we define helium source rock as " $a$ kind of rock that can generate and release large amounts of helium". In order to provide scientific basis for He exploration and reserve estimation, we focus herein on granite and evaluate its potential to be an effective helium source rock, based on analysis of He generation and release behaviors using the granites from the North Qinling Belt as an example. U, Th concentrations were analyzed and EPMA (Electro Probe Microanalysis) images were used to evaluate the characteristics of Uand Th-rich minerals and the productivity of He. He in granites was extracted by crushing and stepwise heating, respectively, for assessing the He release behaviors, including the He release ratios and the influence of fracture and temperature on the release processes. In addition, $\mathrm{K}$ and Ar were also analyzed to assist with the interpretation of the results.

\section{Geological Setting and Sampling}

The Weihe Basin is a Cenozoic graben basin with a large number of faults and fractures within the basin and the basement. The Cenozoic strata are several kilometers thick and up to over $6 \mathrm{~km}$. There are a large number of granitic bodies distributed or exposed in the Qinling Orogenic Belt (QOB), which is in fault contact with the Weihe Basin to the north (Fig. 2). The helium resource in the Weihe Basin has been assumed to be mainly derived from the QOB (Li et al., 2011; Han et al., 2014). 
The QOB is situated between the North China Block (NCB) and the South China Block (SCB). Detailed studies suggest that the QOB has experienced multistage subduction, accretion, and collision of these two blocks (Dong and Santosh, 2016). After experiencing a significant collision in the Middle to Late Triassic, the QOB evolved into an intra-continental evolutionary process (Zhang et al., 2001), accompanied with magmatism, metamorphism, and deformation (Dong and Santosh, 2016). Most of the granites in the QOB were formed in the Mesozoic and Paleozoic (Wang et al., 2015).

In 2012-2016, 88 granite samples were collected from the 7 rock masses that make up the NQB (North Qinling Belt) to evaluate the average concentrations of He source elements, mainly $\mathrm{U}$ and Th, in the rock masses. In addition, we selected 2 Mesozoic granite samples (14-ZQ and 14-HNP) with high U and Th concentrations to study the He generation and release behaviors within these units. The two samples were collected from Zhuque forest park $\left(33^{\circ} 49^{\prime} 25^{\prime \prime} \mathrm{N}, 108^{\circ} 31^{\prime} 48^{\prime \prime E}\right)$ and Huangniupu $\left(34^{\circ} 15^{\prime} 27^{\prime \prime} \mathrm{N}\right.$, $\left.106^{\circ} 54^{\prime} 04 " \mathrm{E}\right)$, respectively. Based on previous investigations on the ages of the adjacent rock masses (shown in Fig. 2), the average ages of the granite samples were calculated to be $212 \mathrm{Ma}$ and $213 \mathrm{Ma}$ for 14HNP and 14ZQ, respectively. This indicates that the plutons formed during the Late Triassic, which corresponds to the timing of the Indosinian movement (Lu, 2000; Zhang et al, 2001).

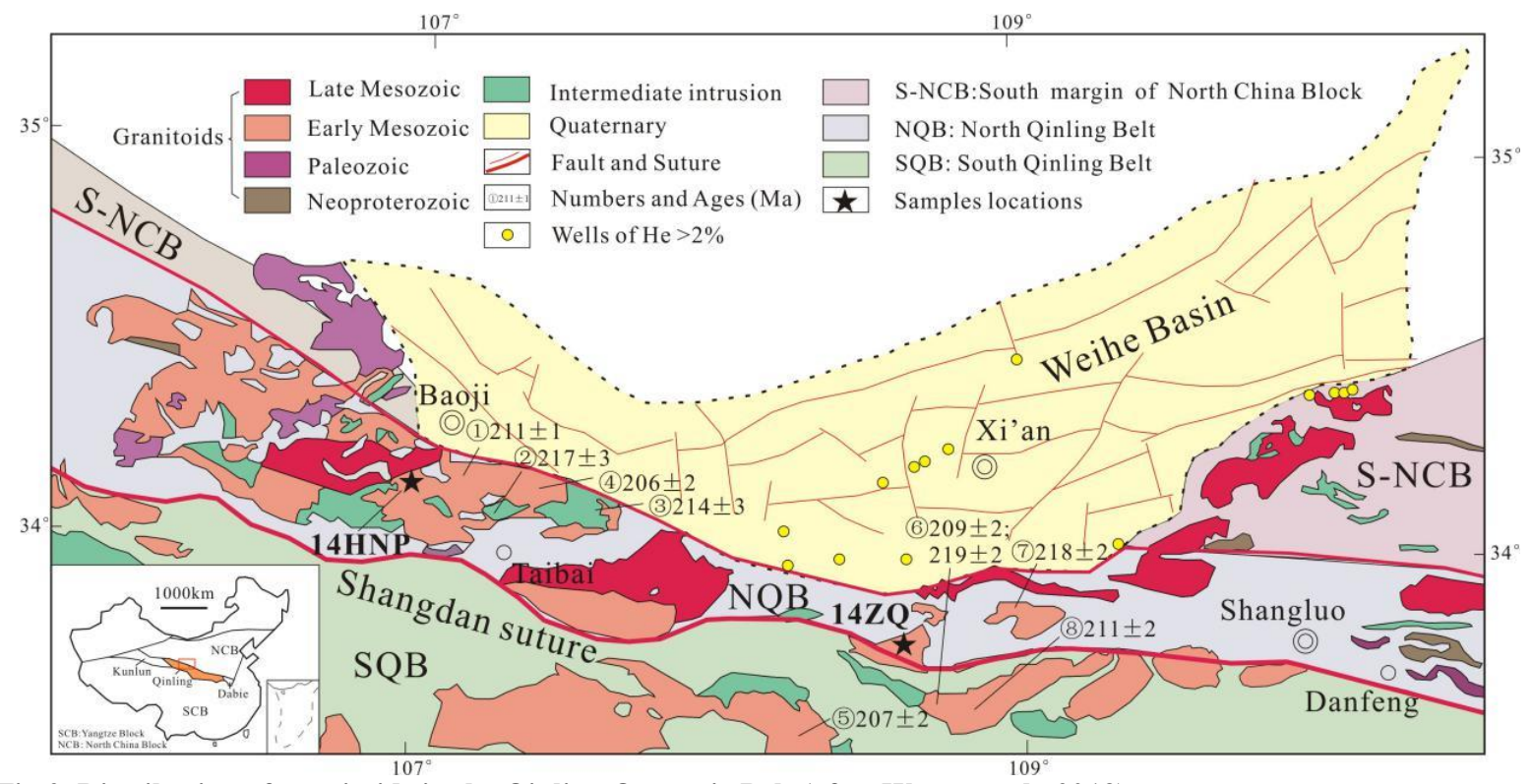

Fig.2. Distribution of granitoids in the Qinling Orogenic Belt (after Wang, et al., 2013).

The age data are cited from Zhang et al. (2006) for (1) (4); Lu et al. (2000) for (2)(3); Dong et al. (2011) for (5); Yang et al. (2009) for (6); Jiang et al. (2010) for (7); and Sun (2002) for (8). China basemap after China National Bureau of Surveying and Mapping Geographical Information.

\section{Analytical Methods}

$\mathrm{U}$ and Th concentrations were measured for 88 granitic samples, in which two samples with high $\mathrm{U}$ and Th contents were selected to do further detailed work, including EPMA and the analysis of $\mathrm{He}$ and $\mathrm{Ar}$ concentrations and isotopic ratios. The reason why we choose U- and Th-rich samples is to evaluate the processes in samples with elevated He quantities and thus a higher precision in the subsequent noble gas testing.

$\mathrm{U}$, Th, and $\mathrm{K}$ concentration analysis and EPMA were performed in the Xi'an Center, China Geology Survey. The instruments used to measure the concentrations of U, Th and K were the Laser Fluorescence Spectrum, AAS (Atomic Absorption Spectrum) and ICP-AES (Inductively Coupled Plasma-Atomic Emission Spectrometry), respectively. To observe morphological features and identify distinguishable phases, SEI (secondary electron images) and BSE (back-scattered electron images) images from EPMA were used. Furthermore, part of U-Th-rich mineral compositions and phase bands were analyzed using a beam spot that was $1-5 \mu \mathrm{m}$ in diameter.

The concentrations and isotopic ratios of $\mathrm{He}$ and Ar were analyzed using a Noblesse noble gas mass spectrometer at the Lanzhou Center for Oil and Gas Resources, Institute of Geology and Geophysics, Chinese Academy of Sciences. The noble gases in rocks were extracted by crushing in the first place, followed by stepwise heating. During the first stage, bulk sample ( $\sim 10 \mathrm{~g}$ and $\sim 3-8 \mathrm{~mm}$ in diameter) was placed into a high-vacuum degassing tank sealed by six sets of bolts, which were fixed to an electromagnetic breaker. The pre-processing crushing system was pumped to lower than $10^{-5} \mathrm{~Pa}$, eliminating air contamination to the maximum extent. Then, the sample was stroke 3000 times in one minute in vacuum with an electromagnetically controlled device, in order to release the gases. The released 
gases were purified first using a spongy titanium furnace to remove active gases, such as $\mathrm{C}_{1}-\mathrm{C}_{4}, \mathrm{H}_{2} \mathrm{O}, \mathrm{N}_{2}$ and $\mathrm{CO}_{2}$ etc., and then using two linked $\mathrm{Zr}-\mathrm{Al}$ getters to remove $\mathrm{H}_{2}$ at ambient temperature. The purified gases were then absorbed in a cryogenic trap at the temperature of 8 degree $\mathrm{K}$ for $20 \mathrm{~min}$. Then $\mathrm{He}$ and $\mathrm{Ar}$ were released under 15 degree $\mathrm{K}$ and 100 degree $\mathrm{K}$ respectively and introduced into the Noblesse SFT noble gas mass spectrometer separately for $\mathrm{He}$ and Ar concentrations and isotopic ratios measurement (Cao et al., 2018).

The crushed sample was then wrapped in $\mathrm{Al}$ foil and placed into a sample disk, which was connected to the double-vacuum high-temperature furnace. The whole system was evacuated for over 24 hours to eliminate air contamination. Noble gases were extracted using stepwise heating in a double-vacuum furnace at $250^{\circ} \mathrm{C}, 700^{\circ} \mathrm{C}, 1100^{\circ} \mathrm{C}$ and $1600^{\circ} \mathrm{C}$ successively, with the duration of each extraction step being 40 minutes. The purification and measuring processes of gases released by heating were the same as those extracted by crushing. During the whole process, air collected from the top of Gaolan Mountain in Lanzhou City, China was used as an internal standard. An air standard was analysed for each sample and the air standard results are reproducible, suggesting that the whole analysis system is stable and the testing results are credible. The experimental uncertainties for both $\mathrm{He}$ and $\mathrm{Ar}$ were $<10 \%$.

\section{Results}

\section{1 $\mathrm{U}$, Th and $\mathrm{K}$ concentrations in granites}

The average $\mathrm{U}$ and Th concentrations in 7 granitic plutons ( 88 samples) and 2 granitic samples are listed in Table 1. The parameter of $[\mathrm{U}+0.24 \mathrm{Th}]$ is applied to evaluate the helium production capacity, where 0.24 is the ratio of the He production rate of Th to that of $\mathrm{U}$ (Zartman et al., 1961). It can be seen that the granites in NQB record high concentrations of $U$ and Th. The average [U+0.24Th] values of 7 plutons range from 7.27 to $16.82 \mathrm{ppm}$, which are 1.5-3.4 times of the average value in the crust $(5.00 \mathrm{ppm})$. The average $[\mathrm{U}+0.24 \mathrm{Th}]$ value in the crust is calculated based on the Clark values of $\mathrm{U}$ and Th $(2.7$ and 9.6ppm, Taylor and McLennan, 1985). The two samples with the highest [U+0.24Th] values, i.e., $14 \mathrm{ZQ}(\mathrm{U}+0.24 \mathrm{Th}=45.4$ $\mathrm{ppm})$ and $14 \mathrm{HNP}(\mathrm{U}+0.24 \mathrm{Th}=17.5 \mathrm{ppm})$, were used for further He and Ar concentrations and isotopic ratios analysis.

The concentrations of $\mathrm{K}$ in samples $14 \mathrm{ZQ}$ and $14 \mathrm{HNP}$ are $2.46 \%$ and $3.44 \%$ respectively, slightly higher than the Clark Value of K (2.09\%, Taylor and McLennan, 1985). It suggests that there is not much difference in the Ar productivity between granite and other types of rocks.

Table $1 \mathrm{U}$, Th and $\mathrm{K}$ concentrations in granitic samples from North Qinling Orogen, China

\begin{tabular}{|c|c|c|c|c|c|}
\hline Sample ID & Number of samples & $\mathrm{U}(\mathrm{ppm})$ & Th (ppm) & $\mathrm{U}+0.24 \mathrm{Th}^{\mathrm{a}}(\mathrm{ppm})$ & $\mathrm{K}(\mathrm{wt} \%)$ \\
\hline Baoji Pluton $^{b}$ & 19 & 3.94 & 18.32 & 8.33 & - \\
\hline Taibai Pluton & 12 & 3.97 & 21.63 & 9.16 & - \\
\hline Cuihuashan Pluton & 12 & 9.41 & 15.77 & 13.20 & - \\
\hline Lantian Pluton & 17 & 6.29 & 17.67 & 16.82 & - \\
\hline Muhuguan Pluton & 6 & 3.45 & 15.92 & 7.27 & - \\
\hline Huashan Pluton & 7 & 4.07 & 11.37 & 6.80 & - \\
\hline Laoniushan Pluton & 11 & 4.17 & 20.35 & 9.06 & - \\
\hline $14 Z Q$ & 1 & 38.5 & 28.7 & 45.38 & 2.46 \\
\hline 14HNP & 1 & 13.6 & 16.4 & 17.54 & 3.44 \\
\hline Clark Value & - & 2.7 & 9.6 & 5.00 & 2.09 \\
\hline
\end{tabular}

${ }^{a} 0.24$ is the ratio of the He production rate of Th to that of $U$ (Zartman et al., 1961)

${ }^{\mathrm{b}}$ The listed $\mathrm{U}$ and $\mathrm{Th}$ concentrations are the average ones for the 7 plutons.

c Clark Values are quoted from Taylor and McLennan (1985).

\subsection{EPMA results}

EPMA images indicate that U- and Th-rich minerals are widely distributed throughout the samples (Fig. 3 ), as is consistent with the high $\mathrm{U}$ and Th contents of these rocks, according to our chemical analysis shown above. Grain sizes of those minerals range from $10 \mu \mathrm{m}$ to $200 \mu \mathrm{m}$, except for a single elongate grain $(\sim 600 \mu \mathrm{m}$, shown in Fig. 3f).

The numbered dots in Fig. 3 show the components that were analyzed. Due to the ubiquitous isomorphic replacement in accessory minerals, it is often difficult to unambiguously identify the minerals. Therefore, we tentatively identified the minerals by their main elements ( $>10 \mathrm{wt} \%$ for its oxide) when it is uncertain. As we can see in Fig. 3, U and Th are mostly concentrated in uranothorite (No. 1) and thorite (No. 4), or are associated with $\mathrm{Ti}, \mathrm{Nb}$ and $\mathrm{Y}$ (No. 2, 6). Part of $\mathrm{U}$ and $\mathrm{Th}$ are present in monazite (No. 3, 5), apatite (Fig. 3a), xenotime (Fig. 3c), magnetite (Fig. 3c), and zircon (Fig. 3d). These U- and Th-rich minerals are distributed within magmatic minerals, such as K-feldspar (Fig. 3a), albite (Fig. 3d) and quartz (Fig. 3e) or between them (Figs. 3b, e, f). 

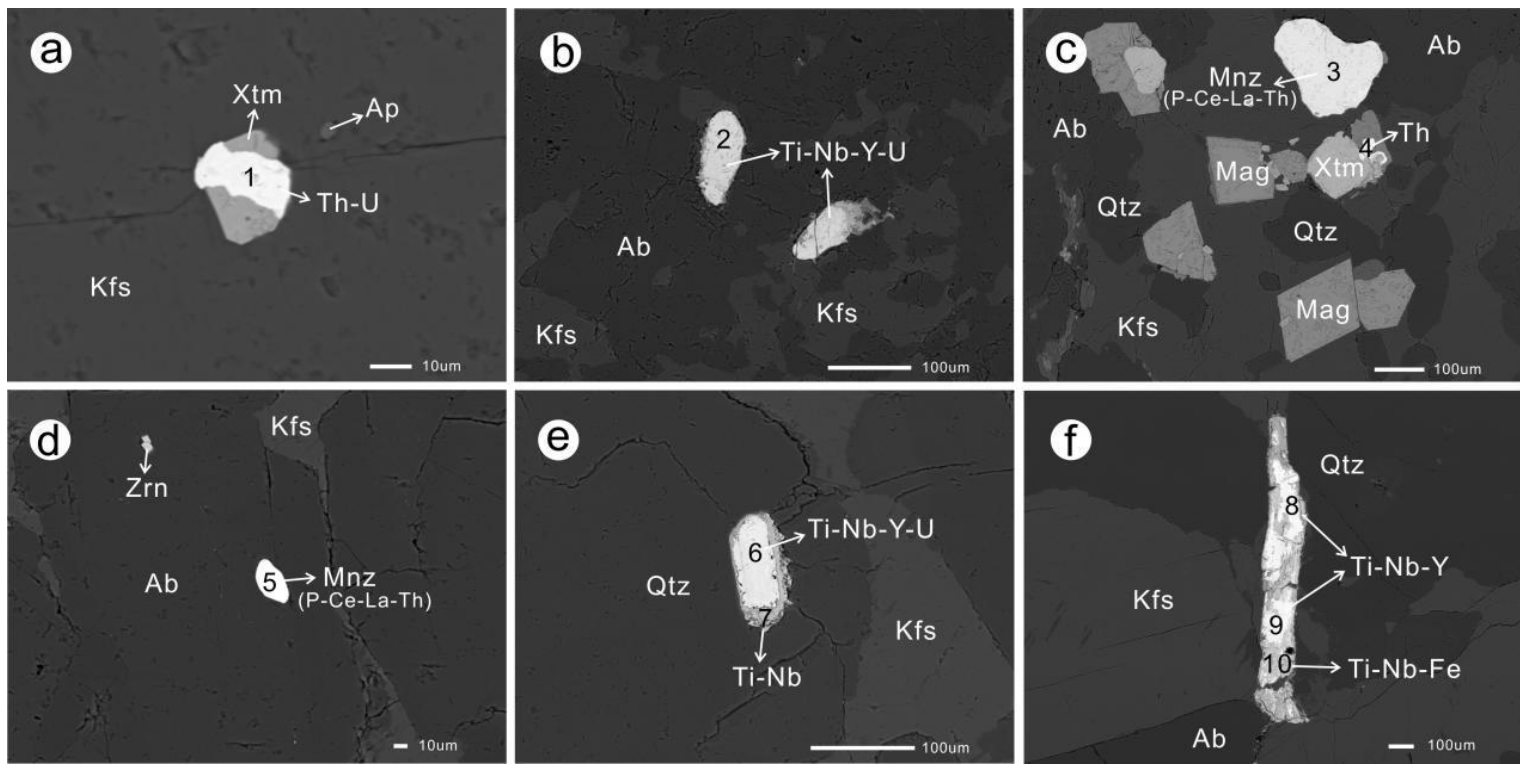

Fig.3. Representative BSE (backscattered electron) images of granites from the Qinling Orogen, China.

(a)-(c) are from sample 14ZQ; (d)-(f) are from sample 14HNP. The grain sizes range from $10 \mu \mathrm{m}$ to $200 \mu \mathrm{m}$, except for a single elongate accessory mineral $(\sim 600 \mu \mathrm{m})$, which is shown in (f). $\mathrm{U}$ and Th are mostly concentrated in thorite (No. 1) and uranothorite (No. 4), and associated with Ti, Nb, $\mathrm{Y}$ (No. 2, 6). U- and Th-bearing minerals include monazite (No. 3, 5), apatite (a), xenotime (c), magnetite (c), and zircon (d). Th-U: uranothorite; Th: thorite; Qtz: Quartz; Kfs: K-feldspar; Ab: Albite; Xtm: Xenotime; Ap: Apatite; Mag: Magnetite; Zrn: Zircon; Mnz: Monazite.

\subsection{He and Ar geochemistry in granites}

\subsubsection{He concentrations and ${ }^{3} \mathrm{He} /{ }^{4} \mathrm{He}$ ratios}

The concentrations and isotopic ratios of He are presented in Table 2. The He contents of samples 14ZQ and $14 \mathrm{HNP}$ measured by crushing are 0.949 and $0.129 \mathrm{ucm}^{3} \mathrm{STP} / \mathrm{g}$, respectively. The ${ }^{3} \mathrm{He} /{ }^{4} \mathrm{He}$ ratios in the two samples are $0.016 \mathrm{R}_{\mathrm{A}}$ and $0.056 \mathrm{R}_{\mathrm{A}}$, respectively; thus, both exhibit characteristics of a crustally-derived source (0.008Ra, Ballentine and Burnard, 2002).

The stepwise heating results (Table 2, Fig. 4) show that the total amounts of He released from 14ZQ and 14HNP are 114.74 and $7.76 \mathrm{ucm}^{3} \mathrm{STP} / \mathrm{g}$, respectively. In addition, most of the He $(80.47 \%$ for 14ZQ and $78.68 \%$ for $14 \mathrm{HNP}$ ) was released at a temperature of $700^{\circ} \mathrm{C}$. The residual $\mathrm{He}$ in the rock was mainly released at $1100^{\circ} \mathrm{C}$ before final heating to $1600^{\circ} \mathrm{C}$. These ${ }^{3} \mathrm{He} /{ }^{4} \mathrm{He}$ ratios are similar to those obtained by crushing, and both record typical features of crust-derived He: ranging from $0.003 \mathrm{R}_{\mathrm{A}}$ to $0.572 \mathrm{R}_{\mathrm{A}}$ (average $0.033 \mathrm{R}_{\mathrm{A}}$ ) for $14 \mathrm{ZQ}$ and from $0.009 \mathrm{R}_{\mathrm{A}}$ to $0.036 \mathrm{R}_{\mathrm{A}}$ (average $0.030 \mathrm{R}_{\mathrm{A}}$ ) for $14 \mathrm{HNP}$. However, due to the low He concentrations extracted from $14 \mathrm{ZQ}$ at $250^{\circ} \mathrm{C}$ and from $14 \mathrm{HNP}$ at $250^{\circ} \mathrm{C}$ and $1600^{\circ} \mathrm{C}$, the experimental errors of their corresponding ${ }^{3} \mathrm{He} /{ }^{4} \mathrm{He}$ ratios are too large for these results to be meaningful. We can see that the minimum ${ }^{3} \mathrm{He} /{ }^{4} \mathrm{He}$ ratios appeared at $1100^{\circ} \mathrm{C}$, while the maximum $\mathrm{He}$ concentrations occurred at $700^{\circ} \mathrm{C}$ (Fig. 4), possibly reflecting the better retention of ${ }^{3} \mathrm{He}$ than ${ }^{4} \mathrm{He}$ in granite rocks.

Table 2 He and Ar concentrations, isotopic ratios in granites from Qinling Orogen, China

\begin{tabular}{|c|c|c|c|c|c|c|}
\hline Sample ID & Extractior & & $\begin{array}{l}{ }^{4} \mathrm{He}(1 \sigma) \\
\mathrm{ucm}^{3} \text { STP/g }\end{array}$ & $\mathrm{R} / \mathrm{R}_{\mathrm{A}}{ }^{\mathrm{a}}(1 \sigma)$ & $\begin{array}{l}{ }^{40} \operatorname{Ar}(1 \sigma) \\
\mathrm{ucm}^{3} \text { STP/g }\end{array}$ & ${ }^{40} \mathrm{Ar} /{ }^{36} \mathrm{Ar}(1 \sigma)$ \\
\hline \multirow{6}{*}{$14 Z Q$} & Crushing & & $0.949 \pm 0.001$ & $0.016 \pm 0.002$ & $12.79 \pm 0.01$ & $294.00 \pm 0.92$ \\
\hline & \multirow{5}{*}{$\begin{array}{l}\text { Stepwise } \\
\text { heating }\end{array}$} & $250^{\circ} \mathrm{C}$ & $0.001 \pm 0.0002$ & - & $0.82 \pm 0.003$ & $244.45 \pm 30$ \\
\hline & & $700^{\circ} \mathrm{C}$ & $92.336 \pm 0.11$ & $0.039 \pm 0.002$ & $5.77 \pm 0.002$ & $348.14 \pm 2.8$ \\
\hline & & $1100^{\circ} \mathrm{C}$ & $22.203 \pm 0.01$ & $0.003 \pm 0.0006$ & $15.65 \pm 0.004$ & $1811.48 \pm 50$ \\
\hline & & $1600^{\circ} \mathrm{C}$ & $0.200 \pm 0.0007$ & $0.572 \pm 0.07$ & $1.97 \pm 0.001$ & $334.86 \pm 13$ \\
\hline & & Total & 114.740 & 0.033 & 24.20 & 702.71 \\
\hline \multirow{6}{*}{$14 \mathrm{HNP}$} & Crushing & & $0.129 \pm 0.001$ & $0.056 \pm 0.013$ & $4.09 \pm 0.004$ & $304.41 \pm 1.70$ \\
\hline & \multirow{5}{*}{$\begin{array}{l}\text { Stepwise } \\
\text { heating }\end{array}$} & $250^{\circ} \mathrm{C}$ & $0.001 \pm 0.0001$ & - & $0.72 \pm 0.0003$ & $201.81 \pm 14$ \\
\hline & & $700^{\circ} \mathrm{C}$ & $6.108 \pm 0.016$ & $0.036 \pm 0.003$ & $4.06 \pm 0.0087$ & $518.44 \pm 6.7$ \\
\hline & & $1100^{\circ} \mathrm{C}$ & $1.653 \pm 0.0006$ & $0.009 \pm 0.004$ & $28.70 \pm 0.013$ & $4121.55 \pm 140$ \\
\hline & & $1600^{\circ} \mathrm{C}$ & $0.001 \pm 0.0001$ & - & $2.00 \pm 0.0001$ & $482.19 \pm 14$ \\
\hline & & Total & 7.761 & 0.030 & 35.49 & 1575.07 \\
\hline
\end{tabular}

${ }^{\mathrm{a}} \mathrm{R}$ is the ratio of ${ }^{3} \mathrm{He} /{ }^{4} \mathrm{He}$ for sample; $\mathrm{R}_{\mathrm{A}}$ is the atmospheric ratio of ${ }^{3} \mathrm{He} /{ }^{4} \mathrm{He}=1.4 \times 10^{-6}$. 


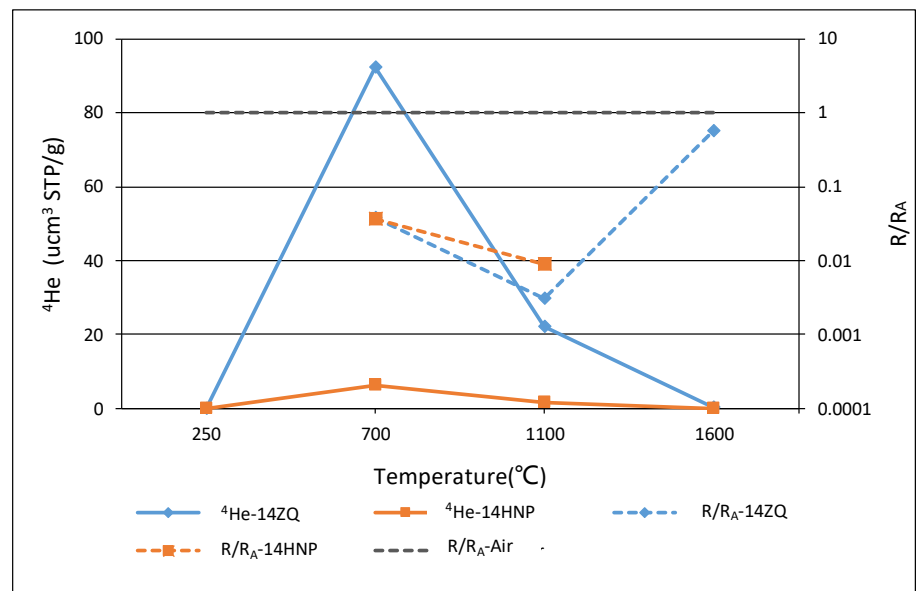

Fig.4. He concentrations and isotopic ratios released by stepwise heating.

Most $\mathrm{He}(80.47 \%$ for $14 \mathrm{ZQ}$ and $78.68 \%$ for $14 \mathrm{HNP})$ is released at a temperature of $700^{\circ} \mathrm{C}$, whereas the $\mathrm{R} / \mathrm{R}_{\mathrm{A}}$ reaches its peak at $1100^{\circ} \mathrm{C}$, potentially suggesting better retention of ${ }^{3} \mathrm{He}$ than ${ }^{4} \mathrm{He}$. Isotopic data at $250^{\circ} \mathrm{C}(14 \mathrm{ZQ}$ and $14 \mathrm{HNP})$ and $1600^{\circ} \mathrm{C}(14 \mathrm{HNP})$ are absent due to their unacceptable errors produced by the low $\mathrm{He}$ concentrations released at these temperatures. The ${ }^{3} \mathrm{He} /{ }^{4} \mathrm{He}$ ratios ranging from $0.003 \mathrm{R}_{\mathrm{A}}$ to $0.572 \mathrm{R}_{\mathrm{A}}$ are typical of crust-derived He.

\subsubsection{Ar contents and ${ }^{40} \mathrm{Ar} /{ }^{36} \mathrm{Ar}$ ratios}

The ${ }^{40} \mathrm{Ar}$ concentrations and ${ }^{40} \mathrm{Ar} /{ }^{36} \mathrm{Ar}$ isotopic ratios of these samples were also measured following crushing and stepwise heating. In the crushing experiments, $14 Z \mathrm{Z}$ released higher ${ }^{40} \mathrm{Ar}$ content $(16.25$ $\mathrm{ucm}^{3} \mathrm{STP} / \mathrm{g}$ ), with a ${ }^{40} \mathrm{Ar} /{ }^{36} \mathrm{Ar}$ isotopic ratio (294.00) similar to that of the atmosphere (295.99, Sano et al., 2013). Gas released from $14 \mathrm{HNP}$ has a lower ${ }^{40} \mathrm{Ar}$ content $\left(5.15 \mathrm{ucm}{ }^{3} \mathrm{STP} / \mathrm{g}\right)$, but a higher ${ }^{40} \mathrm{Ar} /{ }^{36} \mathrm{Ar} \mathrm{ratio}$ (304.41), indicating that partial radiogenic ${ }^{40} \mathrm{Ar}$ was released during $14 \mathrm{HNP}$ crushing.

Results of stepwise heating (Table 2 , Fig. 5) show that in both samples, the released ${ }^{40} \mathrm{Ar}$ contents reach their peak values at $1100^{\circ} \mathrm{C}\left(15.65 \mathrm{ucm}^{3} \mathrm{STP} / \mathrm{g}\right.$ for $14 \mathrm{ZQ}$ and $28.70 \mathrm{ucm}^{3} \mathrm{STP} / \mathrm{g}$ for $\left.14 \mathrm{HNP}\right)$, which correspond to the temperature that released $\mathrm{Ar}$ with maximum ${ }^{40} \mathrm{Ar} /{ }^{36} \mathrm{Ar}$ isotopic ratios (1811.48 for $14 \mathrm{ZQ}$ and 4121.55 for $14 \mathrm{HNP})$. It is clear that ${ }^{40} \mathrm{Ar}$ is mainly released at $1100^{\circ} \mathrm{C}$ and thus at a higher temperature than ${ }^{4} \mathrm{He}\left(700^{\circ} \mathrm{C}\right)$, indicating the higher mobility of He relative to Ar, which could be related to the smaller molecular radius of $\mathrm{He}$ than Ar.

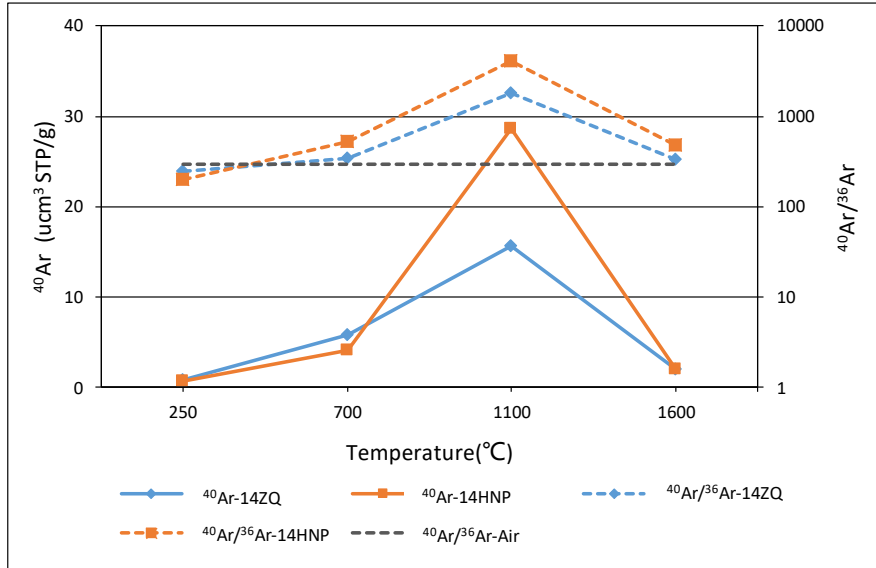

Fig.5. Ar concentrations and isotopic ratios extracted by stepwise heating.

A large proportion of $\mathrm{Ar}$ was released at $1100^{\circ} \mathrm{C}(64.64 \%$ for $14 \mathrm{ZQ}$ and $82.55 \%$ for $14 \mathrm{HNP})$, corresponding to the ${ }^{40} \mathrm{Ar} /{ }^{36} \mathrm{Ar}$ peak. Compared to the temperature range that released the most $\mathrm{He}$ in Fig. $4\left(250-700^{\circ} \mathrm{C}\right)$, it is obvious that $\mathrm{Ar}$ has a better retention capacity than $\mathrm{He}$.

\subsubsection{Comparison of the crushing and stepwise heating results}

The He contents extracted by crushing are only $0.82 \%$ and $1.65 \%$ of the total released He quantities for 14ZQ and 14HNP, respectively. These results are slightly lower than those of Matsumoto et al. (2002), who suggested that $\sim 4.37 \%$ of the total He content was released by crushing in Archean komatiites. Furthermore, Tolstkhin et al. (2016) calculated that this proportion was $\sim 3 \%$ for amphibole in alkaline granites. The differences between these results are likely caused by the diverse $U$ and Th contents used in the samples. When the $\mathrm{U}$ and Th contents are higher, the proportion of radiogenic He sited in matrix is higher, and the proportion of matrix-sited He released by crushing is lower. Comparing the two samples in this work, sample 14ZQ has higher $\mathrm{U}$ and Th concentrations than $14 \mathrm{HNP}$ and yielded a lower proportion of $\mathrm{He}$ released by crushing. The ${ }^{3} \mathrm{He} /{ }^{4} \mathrm{He}$ ratios released by crushing and stepwise heating are both 
typically radiogenic.

Based on the same calculation method, the proportions of radiogenic ${ }^{40} \mathrm{Ar}^{*}$ (where ${ }^{40} \mathrm{Ar}^{*}=$ ${ }^{40} \mathrm{Ar}-295.5 \times{ }^{36} \mathrm{Ar}$ ) released by crushing are $0.00 \%$ and $0.41 \%$ for $14 \mathrm{ZQ}$ and $14 \mathrm{HNP}$, respectively. The proportions of ${ }^{40} \mathrm{Ar} *$ released by crushing are lower than those of He. This can be explained by the smaller molecule and higher mobility of $\mathrm{He}$ than those of $\mathrm{Ar}$. The ${ }^{40} \mathrm{Ar} /{ }^{36} \mathrm{Ar}$ ratios obtained by stepwise heating are $2-5$ times larger than those extracted by crushing, thus suggesting that more radiogenic ${ }^{40} \mathrm{Ar} *$ was released during stepwise heating.

\subsubsection{He and Ar diffusion coefficients in granites}

Based on the He and Ar extraction results by stepwise heating, their diffusion coefficients (Table 3) can be calculated using the spherical diffusion equation presented by Fechtig and Kalbitzer (1966). Since the mean particle size in stepwise heating experiments is $\sim 200 \mu \mathrm{m}$, the radius $(r)$ of the spherical diffusion domain is assumed to be $100 \mu \mathrm{m}$. The diffusivity of Ar in this study is assessed with radiogenic ${ }^{40} \mathrm{Ar} *$.

The He diffusion coefficient in fine-grained $(\mathrm{r}=\sim 100 \mu \mathrm{m})$ granite particles are $4.46-4.82 \times 10^{-9} \mathrm{~cm}^{2} / \mathrm{s}$ at $700^{\circ} \mathrm{C}$. At $1100^{\circ} \mathrm{C}$, the coefficient of He rises to $2.00-3.05 \times 10^{-8} \mathrm{~cm}^{2} / \mathrm{s}$. The diffusion coefficients of Ar are $1.30-13.7 \times 10^{-11} \mathrm{~cm}^{2} / \mathrm{s}$ at $700^{\circ} \mathrm{C}$, lower than those of $\mathrm{He}$ by two orders of magnitude. At $1100^{\circ} \mathrm{C}$, the diffusion coefficients of $\operatorname{Ar}\left(1.51-1.71 \times 10^{-8} \mathrm{~cm}^{2} / \mathrm{s}\right)$ are lower than those of He by approximately 1.5 times.

Table 3 Results of stepwise heating and calculated He and Ar diffusion coefficients

\begin{tabular}{|c|c|c|c|c|c|c|c|}
\hline Sample & $\begin{array}{l}\mathrm{T} \\
{ }^{\circ} \mathrm{C}\end{array}$ & $\begin{array}{l}{ }^{4} \mathrm{He} \\
\mathrm{ucm}{ }^{3} \mathrm{STP} / \mathrm{g}\end{array}$ & Fractional loss & $\begin{array}{l}\mathrm{D} \\
\mathrm{cm}^{2} / \mathrm{s}\end{array}$ & $\begin{array}{l}{ }^{40} \mathrm{Ar}^{*} \\
\mathrm{ucm}{ }^{3} \mathrm{STP} / \mathrm{g}\end{array}$ & Fraction & $\begin{array}{l}\mathrm{D} \\
\mathrm{cm}^{2} / \mathrm{s}\end{array}$ \\
\hline \multirow{4}{*}{ 14ZQ } & 250 & 0.001 & $0.00 \%$ & - & 0.00 & $0.00 \%$ & - \\
\hline & 700 & 92.335 & $80.48 \%$ & $4.82 \times 10^{-9}$ & 0.87 & $6.15 \%$ & $1.37 \times 10^{-11}$ \\
\hline & 1100 & 22.203 & $99.83 \%$ & $2.00 \times 10^{-8}$ & 13.09 & $98.37 \%$ & $1.71 \times 10^{-8}$ \\
\hline & 1600 & 0.200 & $100.00 \%$ & - & 0.23 & $100.00 \%$ & - \\
\hline \multirow{4}{*}{$14 \mathrm{HNP}$} & 250 & 0.001 & $0.01 \%$ & - & 0.00 & $0.00 \%$ & - \\
\hline & 700 & 6.108 & $78.69 \%$ & $4.46 \times 10^{-9}$ & 1.75 & $5.99 \%$ & $1.30 \times 10^{-11}$ \\
\hline & 1100 & 1.653 & $99.98 \%$ & $3.05 \times 10^{-8}$ & 26.65 & $97.34 \%$ & $1.51 \times 10^{-8}$ \\
\hline & 1600 & 0.001 & $100.00 \%$ & - & 0.78 & $100.00 \%$ & - \\
\hline
\end{tabular}

\section{Discussions}

\subsection{He sited in fluid inclusions and minerals matrix in granite}

It is generally agreed that fluid inclusions (FIs) and mineral matrix are the two main reservoirs for $\mathrm{He}$ and other noble gases in rocks (Scarsi, 2000; Barry et al., 2015). Common extraction techniques include crushing, the stepwise heating of powders following crushing (Graham et al., 1992), and laser extraction (Scarsi, 2000). Although crushing under high-vacuum conditions is commonly used to extract He in FIs to trace processes that occurred before the formation of minerals and rocks (Day et al. 2015), it has been demonstrated that matrix-sited He may also be released during this process (Hilton et al., 1993; Matsumoto et al., 2002; Moreira et al., 2003). Furthermore, previous step-crushing studies have suggested that a negligible amount of gas from the matrix can be released by crushing during a short period (Scarsi, 2000; Hilton et al., 2011; Barry et al., 2015; Tolstkhin et al., 2016).

In this study, we assume that a small portion of matrix-sited He can be extracted by crushing. In addition, the ${ }^{4} \mathrm{He}$ obtained by crushing is composed of the ${ }^{4} \mathrm{He}$ in both FIs and the matrix, as follows:

${ }^{4} \mathrm{He}_{\text {crushing }}={ }^{4} \mathrm{He} \mathrm{e}_{\mathrm{FI}}+\mathrm{X}_{4} \cdot{ }^{4} \mathrm{He}_{\text {matrix }}$

where $\mathrm{X}_{4}$ is the proportion of the matrix-sited ${ }^{4} \mathrm{He}$ released by crushing. Then, the ${ }^{4} \mathrm{He}$ extracted by stepwise heating is the residual radiogenic He:

${ }^{4} \mathrm{He}_{\text {heating }}=\left(1-\mathrm{X}_{4}\right) \cdot{ }^{4} \mathrm{He}_{\text {matrix }}$

Combining the above two equations, we can deduce that:

${ }^{4} \mathrm{He}_{\text {crushing }}={ }^{4} \mathrm{He}_{\mathrm{FIs}}+\mathrm{X}_{4} /\left(1-\mathrm{X}_{4}\right) \cdot{ }^{4} \mathrm{He}_{\text {heating }}$ (3)

An analogous approach can be applied to calculate the ${ }^{3} \mathrm{He}$ in FIs:

${ }^{3} \mathrm{He}_{\text {crushing }}={ }^{3} \mathrm{He}_{\mathrm{FIs}}+\mathrm{X}_{3} /\left(1-\mathrm{X}_{3}\right) \cdot{ }^{3} \mathrm{He}_{\text {heating }}$

Due to the similar geological backgrounds, petrological features and rock-forming ages (Fig. 2) of the two samples, their formation environments are assumed to be the same, which implies that the He trapped in the primary fluid inclusions $\left({ }^{4} \mathrm{He}_{\mathrm{FIs}}\right)$ of the two samples are similar. Additionally, the experimental procedures for the two samples are identical, which allows us to assume the same proportions of matrix-sited He released by crushing $(\mathrm{X})$.

Based on Equation (1 - 4), $\mathrm{X}_{4}$ equals $0.76 \%$ (Table 4) and $\mathrm{X}_{3}$ equals $0.23 \%$, suggesting better retention of ${ }^{3} \mathrm{He}$ than ${ }^{4} \mathrm{He}$, which is in accordance with our results in section 4.3.1 and the $\mathrm{He}$ isotopes retention behaviors in amphibole and some chemical sediments (Tolstikhin, et al., 1996; Tolstikhin, et al., 2016). In addition, the ${ }^{4} \mathrm{He}_{\mathrm{FIs}}$ and ${ }^{3} \mathrm{He}_{\mathrm{FIs}}$ are calculated to be $0.07 \mathrm{ucm}^{3} \mathrm{STP} / \mathrm{g}$ and $0.94 \times 10^{-8} \mathrm{ucm}^{3} \mathrm{STP} / \mathrm{g}$ respectively, thus ${ }^{3} \mathrm{He} /{ }^{4} \mathrm{He}$ in FIs is calculated to be $1.33 \times 10^{-7}$ (Table 4). Based on a simple two-phase mixing model, 
where the ${ }^{3} \mathrm{He} /{ }^{4} \mathrm{He}$ ratios of mantle and crust endmembers are taken as $1.1 \times 10^{-5}$ and $2 \times 10^{-8}$ respectively (Mamyrin and Tolstikhin, 1984), the percentage of mantle-derived $\mathrm{He}$ is calculated as $1.03 \%$, which suggests a mainly crustal source for granites from QOB. These results are consistent with those of Wang et al. (2015), who maintained that the granites exposed in the western Qinling Orogen are primarily I-type and I-A-type rocks, i.e., they were formed from crust rather than mantle. In addition, the matrix-sited He are calculated based on Equation (2), suggesting that most of matrix-sited He (99.24\%) are released by stepwise heating (Table 4).

The calculation above is proposed for the first time in this study to evaluate the relationship between matrix-sited gas and those in fluid inclusions during crushing. However, the calculation in this study has large uncertainties due to the small amounts of samples used here. It is recommended to use more samples $\left(>3\right.$, enough for statistical analysis) to reduce errors. In this work, the high amounts of radiogenic ${ }^{4} \mathrm{He}$ have a big influence on the crushing results. It is recommended that $\mathrm{U}$ - and Th-poor minerals and rocks should be fully characterised when discussing the noble gases of FIs.

Table 4 Calculated He concentrations and isotopic ratios in the FIs and matrix

\begin{tabular}{|c|c|c|c|c|}
\hline & \multicolumn{2}{|l|}{ 14ZQ } & \multicolumn{2}{|l|}{$14 \mathrm{HNP}$} \\
\hline & $\begin{array}{l}{ }^{4} \mathrm{He} \\
\mathrm{ucm}^{3} \mathrm{STP} / \mathrm{g}\end{array}$ & $\begin{array}{l}{ }^{3} \mathrm{He} /{ }^{4} \mathrm{He} \\
10^{-8}\end{array}$ & $\begin{array}{l}{ }^{4} \mathrm{He} \\
\mathrm{ucm}^{3} \mathrm{STP} / \mathrm{g}\end{array}$ & $\begin{array}{l}{ }^{3} \mathrm{He} /{ }^{4} \mathrm{He} \\
10^{-8}\end{array}$ \\
\hline FIs $^{\mathrm{a}}$ (Extracted by crushing) & 0.07 & 13.30 & 0.07 & 13.30 \\
\hline Matrix $^{b}$ & 115.62 & 4.57 & 7.82 & 4.25 \\
\hline Extracted by crushing $^{\mathrm{c}}$ & $0.88\left(\mathrm{X}_{4}=0.76 \%\right)$ & - & $0.06(X 4=0.76 \%)$ & - \\
\hline Extracted by heating & $114.74(99.24 \%)$ & - & $7.76(99.24 \%)$ & - \\
\hline
\end{tabular}

${ }^{\mathrm{a}} \mathrm{He}_{\text {crushing }}={ }^{4} \mathrm{He}_{\mathrm{FIs}}+\mathrm{X}_{4} /\left(1-\mathrm{X}_{4}\right) \cdot{ }^{4} \mathrm{He}_{\text {heating }}$, assuming that the He concentrations and isotopic compositions in the FIs of the two samples are the same, where $\mathrm{X}_{4}$ is the proportion of the matrix-sited ${ }^{4} \mathrm{He}$ released by crushing; the Ar concentrations and isotopic compositions in the FIs are uncertain, see section 5.1 for details.

${ }^{\mathrm{b}}{ }^{4} \mathrm{He}_{\text {matrix }}={ }^{4} \mathrm{He}_{\text {heating }} /\left(1-\mathrm{X}_{4}\right), \mathrm{He}$ isotopes are the same as the results of stepwise heating.

${ }^{4} \mathrm{He}_{\text {Matrix, extracted by crushing }}={ }^{4} \mathrm{He}_{\text {matrix }}-{ }^{4} \mathrm{He}_{\text {heating }}$

\subsection{He and Ar production and preservation}

Based on the law of radioactive decay, the production of ${ }^{4} \mathrm{He}$ and ${ }^{40} \mathrm{Ar}^{*}$ (in $\mathrm{ucm}^{3} \mathrm{STP} / \mathrm{g}$ ) can be calculated as follows (after Ballentine and Burnard, 2002):

$$
\left[{ }^{4} \mathrm{He}\right]_{\text {calculated }}=(12.06[\mathrm{U}]+2.87[\mathrm{Th}]) \times 10^{-8} \times \mathrm{t}
$$

$\left[{ }^{40} \mathrm{Ar} *\right]_{\text {calculated }}=3.80 \times 10^{-8} \times[\mathrm{K}] \times \mathrm{t}$

where $[U]$ and $[T h]$ are the concentrations of $\mathrm{U}$ and $\mathrm{Th}$ in ppm, respectively; $[K]$ is the $\mathrm{K}$ content in $\mathrm{wt} \% ; t$ is the formation age of granites in year. Dividing the preserved (matrix-sited) He and Ar* contents by the generated $\mathrm{He}$ and $\mathrm{Ar} *$, their apparent retention coefficients can be calculated as $\mathrm{L}\left({ }^{4} \mathrm{He}\right)$ and $\mathrm{L}\left({ }^{40} \mathrm{Ar} *\right)$.

The results show that $\mathrm{L}\left({ }^{4} \mathrm{He}\right)$ is $9.93 \%$ and $1.74 \%$ for $14 \mathrm{ZQ}$ and $14 \mathrm{HNP}$, respectively (Table 5). The lower $\mathrm{L}\left({ }^{4} \mathrm{He}\right)$ value of $14 \mathrm{HNP}$ is likely due to the strong weathering and microfissures that are present around its U- and Th-rich minerals (Fig. 3). These results indicate that more than $90 \%$ of the He that has been generated since the formation of the granite has been released during the geological time. However, the values of $\mathrm{L}\left({ }^{40} \mathrm{Ar} *\right)$ are far larger than those of $\mathrm{L}\left({ }^{4} \mathrm{He}\right)$, as they are $71.26 \%$ and $105.81 \%$ for $14 \mathrm{ZQ}$ and 14HNP, respectively (Table 5). The high retention coefficients may indicate that the granites have experienced temperatures that fall above the He closure temperatures of the U- and Th-rich minerals but fall below the Ar closure temperatures of the K-rich minerals, which favours Ar retention.

Table 5 Calculated He and Ar retention coefficients

\begin{tabular}{|c|c|c|c|c|}
\hline & \multicolumn{2}{|c|}{${ }^{4} \mathrm{He}\left(\mathrm{ucm}^{3} \mathrm{STP} / \mathrm{g}\right)$} & \multicolumn{2}{|c|}{${ }^{40} \mathrm{Ar}^{*}\left(\mathrm{ucm}^{3} \mathrm{STP} / \mathrm{g}\right)$} \\
\hline & $14 Z Q$ & $14 \mathrm{HNP}$ & $14 Z Q$ & 14HNP \\
\hline Preserved & 115.62 & 7.82 & 14.20 & 29.17 \\
\hline Generated & 1164.30 & 447.72 & 19.93 & 27.73 \\
\hline $\mathrm{L}$ (apparent retention coefficients) & $9.93 \%$ & $1.74 \%$ & $71.26 \%$ & $105.18 \%$ \\
\hline
\end{tabular}

\subsection{He extracted by stepwise heating: implication of temperature on He release}

Under upper crustal conditions $\left(<150^{\circ} \mathrm{C}\right)$, He diffusion coefficients in crustal minerals of the same size range from $10^{-18} \mathrm{~cm}^{2} / \mathrm{s}$ to $10^{-22} \mathrm{~cm}^{2} / \mathrm{s}$ (Lippolt and Weigel 1988; Trull et al. 1991). In this study, the stepwise heating results suggest that the He diffusion coefficients in fine-grained granite particles $(\mathrm{r}=\sim$ $100 \mu \mathrm{m})$ are $4.46-4.82 \times 10^{-9} \mathrm{~cm}^{2} / \mathrm{s}$ and $2.00-3.05 \times 10^{-8} \mathrm{~cm}^{2} / \mathrm{s}$ at $700^{\circ} \mathrm{C}$ and $1100^{\circ} \mathrm{C}$ respectively (Table 3 ). Based on the approximate calculation formula proposed by Lagerwall and Zimen (1963), the time required for a grain to lose $90 \%$ of its He were calculated, which is $1 \mathrm{Ma}$ for minerals under lower temperature $\left(<150^{\circ} \mathrm{C}\right)$ when the He diffusion coefficient is approximately $10^{-18} \mathrm{~cm}^{2} / \mathrm{s}$, and is 0.001 year $(8.64 \mathrm{~h})$ for granite grains $(\mathrm{r}=\sim 100 \mu \mathrm{m})$ at $700^{\circ} \mathrm{C}$ (Fig. 6), suggesting that He can be closed in minerals under lower temperatures but cannot be trapped under high temperature over geological time. 


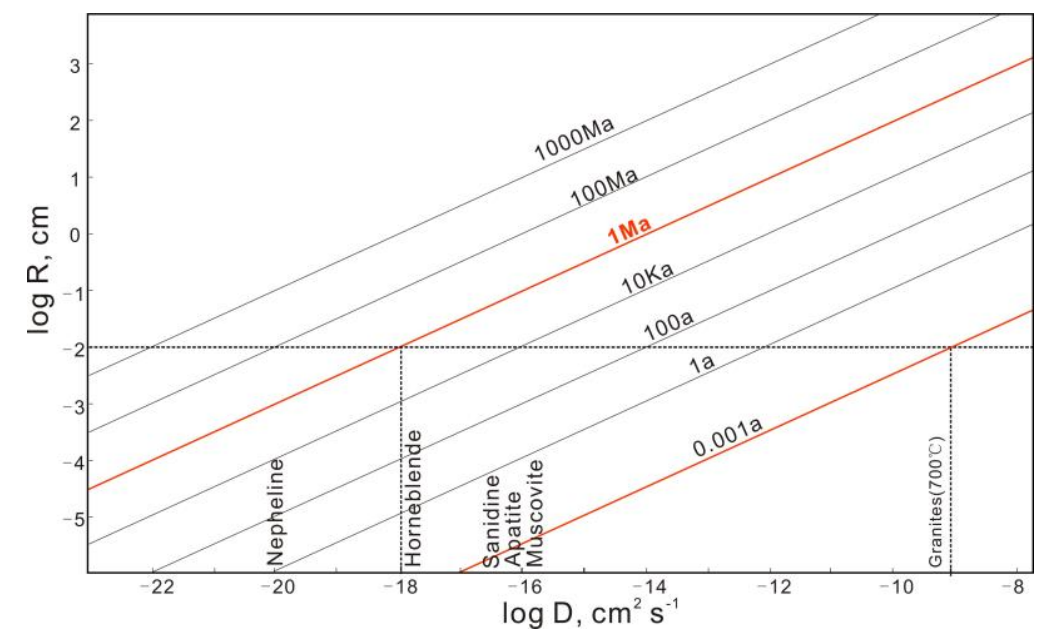

Fig.6. Relationship between grain size, He diffusion coefficient and time required for a grain to lose $90 \%$ of its $\mathrm{He}$ (after Ballentine and Burnard 2002).

The diffusivities of several minerals are measured at $100^{\circ} \mathrm{C}$ (Lippolt and Weigel 1988; McDougall and Harrison 1988; Wolf et al., 1996). The diffusivity of granites at $700^{\circ} \mathrm{C}$ is from this study. The horizontal dashed line indicates that the time required for a granitic grain $(\sim 100 \mu \mathrm{m})$ to lose $90 \%$ of its $\mathrm{He}$ is only 0.001 year $(8.64 \mathrm{~h})$ at $700^{\circ} \mathrm{C}$.

In the past few decades, the influence of temperature on He retention, diffusion, and closure temperature in U- and Th-rich minerals have been researched thoroughly in the field of U-Th-He dating (Wolf et al., 1996; Farley et al., 1996; Flowers et al., 2009). In our samples, U and Th are present in independent minerals (uranothorite, thorite, minerals rich in $\mathrm{Ti}, \mathrm{Nb}, \mathrm{Y}$ and $\mathrm{U}$ ), or isomorphously, in accessory minerals (monazite, apatite, xenotime, magnetite and zircon). Besides, other U- and Th-rich minerals, such as titanite and allanite, are also present in granites. We summarized the He closure temperatures in a variety of $\mathrm{U}$ and Th bearing minerals, which are concentrated between $27-250^{\circ} \mathrm{C}$ (Fig.7). Uranium oxide has the lowest He closure temperature $\left(27-76^{\circ} \mathrm{C}\right.$, calculated from Roudil et al., 2008) and it can only conserve $2.1 \%$ (on average) of the He produced since its formation (Roudil et al., 2008). General minerals and $U$ and Th-bearing minerals have variably higher He closure temperatures, which are lower than $250^{\circ} \mathrm{C}$ : fluorite $\left(47-143^{\circ} \mathrm{C}\right.$, Wolff et al., 2016), carbonates $\left(70 \pm 10^{\circ} \mathrm{C}\right.$, Copeland et al., 2007), apatite $\left(75 \pm 7^{\circ} \mathrm{C}\right.$, Wolf et al., 1996), hematite $\left(>90-180^{\circ} \mathrm{C}\right.$, Wernicke and Lippolt, 1997), zircon $\left(170-190^{\circ} \mathrm{C}\right.$, Reiners, et al., 2002), titanite $\left(191-218^{\circ} \mathrm{C}\right.$, Reiners, et al., 1999), monazite $\left(241^{\circ} \mathrm{C}\right.$ on average, Boyce et al., 2005) and magnetite $\left(250^{\circ} \mathrm{C}\right.$, Blackburn et al., 2007). Thus, it is harder to retain $\mathrm{He}$ in these U- and Th-bearing minerals at temperatures above $250^{\circ} \mathrm{C}$ on the geological time scale.

On the other hand, the Ar closure temperatures are higher than those of He by over $100^{\circ} \mathrm{C}$ for general mineral grain sizes in crustal rocks (Ballentine and Burnard, 2002). For example, the Ar closure temperatures of hornblende and biotite are $\sim 700^{\circ} \mathrm{C}$ and $350-400^{\circ} \mathrm{C}$, respectively (Berger et al., 1981). All the evidence indicates that Ar has better retention and lower mobility than He, which can be readily explained by the larger atomic radius of Ar than that of He.

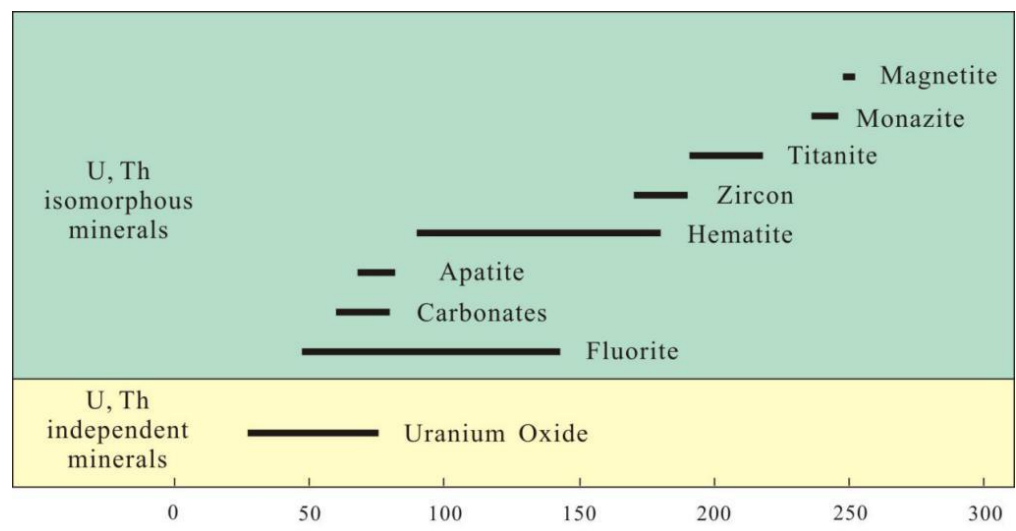

Fig.7. He closure temperatures of U-Th-bearing minerals.

Uranium oxide $\left(27-76^{\circ} \mathrm{C}\right.$, calculated from Roudil et al., 2008); fluorite (47-143 ${ }^{\circ} \mathrm{C}$, Wolff et al., 2016); carbonates $\left(70 \pm 10^{\circ} \mathrm{C}\right.$, Copeland et al., 2007$)$; apatite $\left(75 \pm 7^{\circ} \mathrm{C}\right.$, Wolf et al., 1996); hematite $\left(>90-180^{\circ} \mathrm{C}\right.$, Wernicke and Lippolt, 1997); zircon (170-190 ${ }^{\circ} \mathrm{C}$, Reiners, et al., 2002); titanite (191-218 ${ }^{\circ} \mathrm{C}$, Reiners, et al., 1999$)$; monazite $\left(241^{\circ} \mathrm{C}\right.$ on average, Boyce et al., 2005); magnetite $\left(250^{\circ} \mathrm{C}\right.$, Blackburn et al., 2007$)$.

\subsection{Implication of fracture on He release}


Many phenomena observed in nature suggest that He release is closely associated with fractures: the geothermal wells with high He concentrations are distributed along main faults in the Weihe Basin (Fig. 1, Li et al., 2011; Han et al., 2014); release of He is applied to monitor the stress state of coal seam during coal mining (Zhu et al., 2003); He is also a sensitive indicator for earthquake prediction and activity (Sano et al., 1998; Hong et al., 2010; Umeda et al., 2013; Wei et al., 2016). Since granite has no retention ability for helium under high temperature (Section 5.3), helium is mobilizable rather than closed in minerals in the depth of granitic pluton. Fractures extended to deep geological bodies can further transfer free He from deep source rocks to shallow reservoirs.

Research at Yellowstone National Park in the U.S.A has shown that He accumulated in Archaean cratonic rocks (> 2.5 billion years old) was liberated over the past two million years by intense crustal metamorphism (Lowenstern et al., 2014). Generally, crustal metamorphism is accompanied by the formation of fractures. Young active fractures can mobilize He to adjacent gas fields.

\subsection{A model: granite as a Helium Source Rock}

Based on the U, Th distribution and He concentrations extracted by crushing and stepwise heating obtained from this study, a model on granite as an effective helium source rock is constructed here (Fig. 8). We propose that the extensively distributed granites in the NQB are the most likely source rocks of the He resources accumulated in the Weihe Basin.

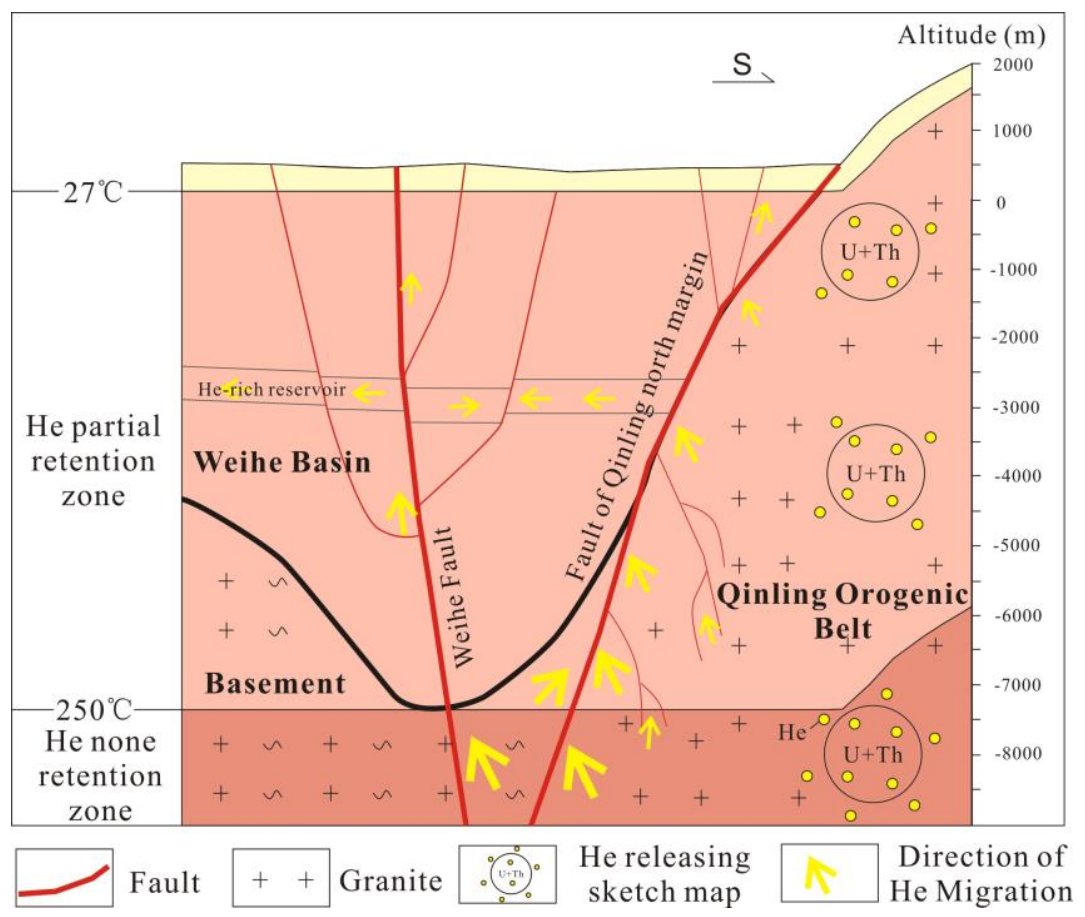

Fig.8. Model of granite as an effective helium source rock in the Weihe Basin.

(1) U- and Th-rich granites can slowly but constantly generate He; (2) Temperature has a pivotal impact on He release from granite. Part of He is retained in minerals and rocks under $27-250^{\circ} \mathrm{C}$, which correspond to $\sim 400 \mathrm{~m}-\sim 7800 \mathrm{~m}$ assuming a $15^{\circ} \mathrm{C}$ surface temperature and a $3^{\circ} \mathrm{C} / 100 \mathrm{~m}$ geothermal gradient (He partial retention zone). Geologic bodies deeper than $7800 \mathrm{~m}$ are classified as He none retention zone. (3) Fracture system facilitates He release from the source rocks and provides channels to transfer free He from deep source rocks to shallow reservoirs.

Firstly, it has been demonstrated that granites in the NQB are rich in uranium and thorium. The $[\mathrm{U}+0.24 \mathrm{Th}]$ values of 7 granitic plutons from the NQB range from 7.27 to $16.82 \mathrm{ppm}$, which are $1.5-3.4$ times that of the Clark value. $\mathrm{U}$ and Th are present in independent minerals (uranothorite, thorite, minerals rich in $\mathrm{Ti}, \mathrm{Nb}, \mathrm{Y}$, and $\mathrm{U}$ ), or isomorphously, in accessory minerals (monazite, apatite, xenotime, magnetite, zircon, titanite and allanite). Most of the granites in NQB were formed during the Paleozoic and Mesozoic. Based on the radioactive decay law, these granites can slowly but constantly generate radiogenic He. Results show that only $9.93 \%$ and $1.74 \%$ of the He generated since their formation are preserved in the rocks for the two samples. This suggests that more than $90 \%$ of the generated He has been released out of these granitic bodies, some of which may have been accumulated in the Weihe Basin.

Additionally, temperature has a pivotal impact on He release from granite. The He close temperatures of many U- and Th-rich minerals are concentrated between $27^{\circ} \mathrm{C}$ to $250^{\circ} \mathrm{C}$, which correspond to $\sim 400-\sim 7800 \mathrm{~m}$ in depth, assuming a $15^{\circ} \mathrm{C}$ surface temperature and a $3^{\circ} \mathrm{C} / 100 \mathrm{~m}$ geothermal gradient. This suggests that variable amounts of He can be retained in the granite at depths from $400 \mathrm{~m}$ to $7800 \mathrm{~m}$ (He partial retention zone), and part of it was released. At the depths of greater than $7800 \mathrm{~m}$, He may have been completely released, herein termed the He none retention zone. Furthermore, He diffusion experiments under high pressure for olivine 
yield a similar result with those under 1-atm (Cherniak and Watson, 2012), suggesting that high pressure has little impact on He diffusion in rocks at depth. Since He mobilization is controlled by temperature, $\mathrm{He}$ is easier to release in regions with a high geothermal gradient.

Fractures further facilitate release of He from the source rocks under high temperatures. They provide channels to the effectively transfer free He from deep source rocks to shallow reservoirs. A fracture system consists of faults, fractures and microfissures. The migration of $\mathrm{He}$ in a fracture system makes the $\mathrm{He}$ concentrations in the fractures lower than the source rocks, further accelerating the He release process from the granites. Relatively young granitic source rocks and active fracture systems can provide large amounts of He to nearby sedimentary basins, such as the Weihe Basin.

Therefore, it is advantageous to explore He resources in hydrocarbon basins with granitic basement (or adjacent to granite), high geothermal field, and young active fractures.

\section{Conclusions}

The characteristics of granites as an effective helium source rock were evaluated using the granites from the Northern Qinling Belt near the Weihe Basin as an example. The following conclusions are made.

(1) The 7 granitic plutons in NQB are rich in $\mathrm{U}$ and Th. The [U+0.24Th] values of these granites range from 7.27 to $16.82 \mathrm{ppm}$, which are 1.5-3.4 times that of the Clark value. $\mathrm{U}$ and Th are present in independent minerals, or isomorphously, in accessory minerals. These granites can slowly but constantly generate radiogenic $\mathrm{He}$.

(2) Temperature has a pivotal impact on He release from granite. Almost all of the $\mathrm{He}(99.24 \%)$ generated by radioactive decay was released in the stepwise heating experiments. He diffusivity $\left(\mathrm{D}_{\mathrm{He}}\right)$ of granites are $4.46-4.82 \times 10^{-9} \mathrm{~cm}^{2} / \mathrm{s}$ at $700^{\circ} \mathrm{C}$ and $2.00-3.05 \times 10^{-8} \mathrm{~cm}^{2} / \mathrm{s}$ at $1100^{\circ} \mathrm{C}$. The $\mathrm{He}$ closure temperatures of many $\mathrm{U}$ - and Th-rich minerals are concentrated between $27^{\circ} \mathrm{C}$ to $250^{\circ} \mathrm{C}$, which corresponds to $\sim 400 \mathrm{~m}$ to $\sim 7800 \mathrm{~m}$ in depth assuming a $15^{\circ} \mathrm{C}$ surface temperature and a $3^{\circ} \mathrm{C} / 100 \mathrm{~m}$ geothermal gradient. It means that part of the He generated by radioactive decay is retained in minerals and rocks from $400 \mathrm{~m}$ to 7800 $\mathrm{m}$ depths (He partial retention zone), and part of it is released. At the depths of greater than $7800 \mathrm{~m}, \mathrm{He}$ is potentially completely mobilized (He none retention zone).

(3) Fractures facilitate release of He from source rocks under high temperatures. They provide channels for the effective transfer of the free He from deep source rocks to shallow reservoirs.

(4) It is advantageous to explore He resources in hydrocarbon basins with granitic basement (or adjacent to granite), high geothermal field, and young active fractures.

(5) Ar has better retention and lower mobility than $\mathrm{He}$, which can be readily explained by the larger atomic radius of $\mathrm{Ar}$ than that of $\mathrm{He}$. More ${ }^{40} \mathrm{Ar}(\sim 71 \%$ and $\sim 105 \%)$ are retained in granitic samples, far higher than $\mathrm{He}(9.93 \%$ and $1.74 \%)$. The diffusion coefficients of $\mathrm{Ar}$ are $1.30-1.37 \times 10^{-11} \mathrm{~cm}^{2} / \mathrm{s}$ and $1.51-1.71 \times 10^{-8} \mathrm{~cm}^{2} / \mathrm{s}$ at $700^{\circ} \mathrm{C}$ and $1100^{\circ} \mathrm{C}$, respectively, lower than those of $\mathrm{He}$.

\section{Acknowledgments}

This study has been supported by the National Science Foundation of China (NSFC, No. 41572131) and the China Geology Survey (DD20190103). We thank Liwu Li and Chunhui Cao for assistance in sample analysis. We acknowledge Prof. Guoxiang Chi for editorial handling and constructive reviews as well as an anonymous reviewer for the helpful comments.

\section{References}

Ballentine, C.J., and Lollar B.S., 2002. Regional groundwater focusing of nitrogen and noble gases into the Hugoton-Panhandle giant gas field, USA. Geochimica et Cosmochimica Acta, 66(14): 2483-2497.

Ballentine, C.J., and Burnard, P.G., 2002. Production, Release and Transport of Noble Gases in the Continental Crust. Reviews in Mineralogy \& Geochemistry, 47(1): 481-538.

Ballentine, C.J., Barry, P.H., Fontijn, K., Hillegonds. D., Bluett, J.J., Abraham-James, T.H., Danabalan, D., Gluyas, J.G., Brennwald, M.S., Pluss, B., Seneshen, D.M., and Lollar B.S., 2017. Continental rifting and ${ }^{4}$ He reserves. Goldschmidt Conference, Yokohama, Japan.

Barry, P.H., Hilton, D.R., Day, J., Pernet-Fisher, J.F., Howarth, G.H., Magna, T., Agashev, A.M., Pokhilenko, N.P., Pokhilenko, L.N., and Taylor, L.A., 2015. He isotopic evidence for modification of the cratonic lithosphere during the Permo-Triassic Siberian flood basalt event. Lithos, 216-217: 73-80.

Berger, G.W., and York, D., 1981. Geothermometry from ${ }^{40} \mathrm{Ar} /{ }^{39}$ Ar dating experiments.Geochimica et Cosmochimica Acta, 45: 795-811.

Brown, A.A., 2010. Formation of high helium gases: A guide for explorationists. AAPG Convention, New Orleans, Louisiana, USA, 11-14.

Cai, Z.M., Clarke, R.H., Glowacki, B.A., Nuttall, W.J., and Ward, N., 2010. Ongoing ascent to the helium production plateau-Insights from system dynamics. Resources Policy, 35: 77-89.

Cao, C.H., Zhang, M.J., Tang, Q.Y., Yang, Y., Lv, Z.G., Zhang, T.W., Chen, C., Yang, H., and Li, L.W., 2018. Noble gas isotopic variations and geological implication of Longmaxi shale gas in Sichuan Basin, China. Marine and Petroleum Geology, 89: 38-46.

Danabalan, D., Gluyas, J.G., Macpherson, C.G., Abraham-James, T.H., Bluett, J.J., Barry, P.H., and Ballentine, C.J., 2016. New high-grade helium discoveries in Tanzania. Goldschmidt Conference, Yokohama, Japan. 
Day, J., Barry, P.H., Hilton, D.R., Burgess, R., Pearson, D.G., and Taylor, L.A., 2015.The helium flux from the continents and ubiquity of low- ${ }^{3} \mathrm{He} /{ }^{4} \mathrm{He}$ recycled crust and lithosphere. Geochimica Et Cosmochimica Acta, 153: 116-133.

Dong, Y.P., Liu, X.M., Zhang, G.W., Chen, Q., Zhang, X.N., Li, W., and Yang, C., 2011. Triassic diorites and granitoids in the Foping area: Constraint on the conversion from subduction to collision in the Qinling orogen, China. Journal of Asian Earth Sciences 47: 123-142.

Dong, Y.P., and Santosh, M., 2016. Tectonic architecture and multiple orogeny of the Qinling Orogenic Belt, Central China. Gondwana Research 29(01): 1-40.

Farley, K.A, Wolf, R.A., and Silver, L.T., 1996. The effects of long alpha-stopping distances on (U-Th)/He ages. Geochimica et Cosmochimica Acta, 60(21): 4223-4229.

Fechtig, H., and Kalbitzer, S., 1966. The diffusion of Ar in potassium-bearing solids. In: Schaeffer, O.A., and Zahringer, J. (Eds.), Potassium Ar Dating. Springer, Heidelberg, Germany, 68-107.

Flower, A. 2012. LNG: The global liquefied natural gas market. In The Future of Helium as a Natural Resource (Eds Nuttall W.J., Clarke, R.H., Glowacki, B.A.), Routledge, Taylor \& Francis Group, London and New York, 69-87.

Flowers, R. M., Ketcham, R.A., Shuster, D.L., and Farley, K.A., 2009. Apatite (U-Th)/He thermochronometry using a radiation damage accumulation and annealing model. Geochimica et Cosmochimica Acta, 73(8): 2347-2365.

Fourré, E., Jean-Baptiste, P., Dapoigny, A., Lavielle, B., Smith, T., Thomas, B., and Vinsot, A., 2011. Dissolved helium distribution in the Oxfordian and Dogger deep aquifers of the Meuse/Haute-Marne area. Physics and Chemistry of the Earth Parts A/B/C, 36: 1511-1520.

Graham, D.W., Humphris, S.E., Jenkins, W.J., and Kurz, M.D., 1992.Helium isotope geochemistry of some volcanic rocks from Saint Helena. Earth and Planetary Science Letters, 110: 121-131.

Hamak, J. E., 2016. Helium, Mineral Commodity Summaries, Helium. Government Printing Office, 78-79.

Han, W., Li, Y.H., Lu, J.C., Ren, Z.L., Xu, W., and Song, B., 2014. The factors responsible for the unusual content of helium-rich natural gas in the Weihe Basin, Shaanixi Province. Geological Bulletin of China, 33: 1836-1841 (in Chinese with English abstract).

Hilton, D.R., Hammerschmidt, K., Loock, G., and Friedrichsen, H., 1993.Helium and argon isotope systematics of the central Lau Basin and ValuFa Ridge: Evidence of crust/mantle interactions in a back-arc basin. Geochimica et Cosmochimica Acta 57: 2819-2841.

Hilton, D.R., Halldórsson, S.A., Barry, P.H., Fischer, T.P., Moor, J.M., Ramirez, C.J., Mangasini, F., and Scarsi, P., 2011.Helium isotopes at Rungwe Volcanic Province, Tanzania, and the origin of East African Plateaux. Geophysical Research Letters 38, 759-775.

Hong, W.L., Yang, T.F., Walia, V., Lin, S.J., Fu, C.C., Chen, Y.G., Sano, Y., Chen, C.H., and Wen, K.L., 2010. Nitrogen as the carrier gas for helium emission along an active fault in NW Taiwan. Applied Geochemistry, 25: 593-601.

Hussain, N., 1997. Flux of ${ }^{4} \mathrm{He}$ from Carnmenellis granite: modelling of an HDR geothermal reservoir. Applied Geochemistry, 12: 1-8.

Jiang, Y.H., Jin, G.D., Liao, S.Y., Zhou, Q., and Zhao, P., 2010. Geochemical and Sr-Nd-Hf isotopic constraints on the origin of Late Triassic granitoids from the Qinling orogen, central China: implications for a continental arc to continent-continent collision. Lithos 117: 183-197.

Li, Y.H., Lu, J.C., Li, J.C., Chen, G.C., and Wei, X.Y., 2011. Distribution of the helium-Rich Wells and Helium Derivation in Weihe Basin. Journal of Jilin University (Earth Science Edition), 41: 47-53 (in Chinese with English abstract).

Li, Y.H., Wang, X.Y., and Han.W., 2015.The status of the survey and results for the prospect of nature heliumgas resources in the Weihe Basin.Geological Survey of china, 2, 1-6 (in Chinese with English abstract).

Li, Y.H., Wang X.Y., and Han W., 2016. Mode of occurrence of helium in Weihe Basin, Shaanxi Province and its significance. Geological Bulletin of China, 35: 372-378 (in Chinese with English abstract).

Liu, J.C., Li, R.X., Wei G.F., and Zhao, F.S., 2009. Origin and Source of Soluble Helium Gas in Geothermal Water, Weihe Basin[J]. Geological Science and Technology Information, 28: 84-88 (in Chinese with English abstract).

Lippolt, H.J., and Weigel, E., 1988. ${ }^{4} \mathrm{He}$ diffusion in ${ }^{40} \mathrm{Ar}$ retentive minerals. Geochimica et Cosmochimica Acta 52: $1449-1458$.

Lowenstern, J.B., Evans, W.C., Bergfeld, D., and Hunt, A.G., 2014. Prodigious degassing of a billion years of accumulated radiogenic helium at Yellowstone. Nature, 506: 355-358.

Lu, X.X., 2000. Tectonic Map of Granitoids in Qinling. Xi'an: Xi'an Geological Publishing House (in Chinese with English abstract).

Matsumoto, T., Seta, A., Matsuda, J.I. Takebe, M. Chen, Y.L., and Arai, S., 2002. Helium in the Archean komatiites revisited: significantly high ${ }^{3} \mathrm{He} /{ }^{4} \mathrm{He}$ ratios revealed by fractional crushing gas extraction. Earth and Planetary Science Letters 196: $213-225$.

Mamyrin, B.A., and Tolstikhin, I.N., 1984. Helium isotopes in nature. Amsterdam: Elsevier.

McDougall, I., and Harrison, T.M., 1988. Geochronology and thermochronology by the ${ }^{40} \mathrm{Ar} /{ }^{39} \mathrm{Ar}$ method. Oxford: Oxford University Press.

Nuttall, W.J., Clarke, R.H., and Glowacki, B. A., 2012. The Future of Helium as a Natural Resource. In: Hanley, N. (Eds.), Routledge Explorations in Environmental Economics, 1-370.

Reiners, P.W., and Farley, K.A., 1999. Helium diffusion and (U-Th)/He thermochronometry of titanite. Geochimica et Cosmochimica Acta, 63: 3845-3859.

Reiners, P.W., Farley, K.A., and Hickes, H.J., 2002. Helium diffusion and (U-Th)/He thermochronometry of zircon: initial results from Fish Canyon Tuff and Gold Butte. Tectonophysics 349: 297-308.

Reinoehl, B., 2012. Pioneering work for the first large helium plant sourced by tail gases from an LNG facility, In The Future of Helium as a Natural Resource (Eds Nuttall W.J., Clarke, R.H., Glowacki, B.A.). London and New York: Routledge, Taylor \& Francis Group, 55-68.

Sabaou, N., Ait-Salem, H., and Zazoun, R.S., 2009. Chemostratigraphy, tectonic setting and provenance of the Cambro-Ordovician clastic deposits of the subsurface Algerian Sahara. Journal of African Earth Sciences, 55: 158-174.

Sano, Y., Takahata, N., Igarashi, G., Koizumi, N., and Sturchio, N.C., 1998. Helium degassing related to the Kobe earthquake. Chemical Geology, 150: 171-179.

Sano, Y., Marty, B., Burnard, P., 2013. Noble Gases in the Atmosphere. In: Burnard, P. (Eds.), The Noble Gases as Geochemical Tracers. Springer-Verlag Berlin Heidelberg, 17-31.

Scarsi, P., 2000. Fractional extraction of helium by crushing of olivine and clinopyroxene phenocrysts: effects on the ${ }^{3} \mathrm{He} /{ }^{4} \mathrm{He}$ measured ratio. Geochimica et Cosmochimica Acta 64: 3751-3762.

Simon, R.B., Michael, L., Janie, C., Rod, E., William, H., Scott, H, Sophia, H., Michael, H., Alan, H., Mike, O., and Cathy T., 2016. Responding to the U.S. research community's liquid helium crisis, issued by APS, MRS and ACS. 
Sun, W.D., Li, S.G., Chen, Y.D., and LI, Y.J., 2002. Timing of synorogenicgranitoids in the South Qinling, central China: constraints on the evolution of the Qinling-Dabieorogenic belt. Journal of Geology, 110: 457-468.

Tao, X.W., Li, J.Z., Zhao, L.B., Li, L.W., Zhu, W.P., Xing, L.T., Su, F.Q., Shan, X.Q., Zheng, H.J., and Zhang, L.P., 2019. Helium resources and discovery of first supergiant helium reserve in China: Hetianhe gas field. Earth Science, 44(3): 1024-1041 (in Chinese with English abstract).

Taylor, S.R., and McLennan, S.M., 1985. The Continental Crust: its Composition and Evolution. Oxford, United States: Blackwell Scientific.

Tolstikhin, I., Lehmann, B.E., Loosli, H.H., and Gautschi, A., 1996. Helium and argon isotopes in rocks, minerals, and related ground waters: A case study in northern Switzerland. Geochimica et Cosmochimica Acta 60: 1497-1514.

Tolstikhin, I., Waber, H.N., Kamensky, I., Loosli, H.H., Skiba, V., and Gannibal, M., 2011. Production, redistribution and loss of helium and argon isotopes in a thick sedimentary aquitard-aquifer system (Molasse Basin, Switzerland). Chemical Geology 286: 48-58.

Tolstikhin, I.N, Verchovsky A.B., Kamensky I.L., Skiba, V.I., Gannibal, M.A., Vetrain, V.R., and Tarakanov, S.V., 2016. Amphibole: A major carrier of He isotopes in crustal rocks. Chemical Geology 444:187-198.

Trull, T.W., Kurz, M.D., and Jenkins, W.J., 1991. Diffusion of cosmogenic ${ }^{3} \mathrm{He}$ in olivine and quartz: Implications for surface exposure dating. Earth and Planetary Science Letters 103: 241-256.

Umeda, K., Asamori, K., and Kusano, T., 2013. Release of mantle and crustal helium from a fault following an inland earthquake. Applied Geochemistry, 2013, 37: 134-141.

Wang, P.Y., Song, T., Zhen, Y.Q., Wu, J.F., and Wu, J., 2011. Sichuan Weiyuan gas field: A typical example for mantle-crust source. Contributions to Geology and Mineral Resource Research, 26: 63-73 (in Chinese with English abstract).

Wang, X.X., Tao, W., and Zhang, C.L., 2015. Granitoid magmatism in the Qinling orogen, central China and its bearing on orogenic evolution. Science China Earth Sciences 58, 1497-1512.

Wei, F.X, Xu, J.D., Shangguan, Z.G., Pan, B., Yu, H.M., Wei, W., Bai, X., and Chen, Z.Q., 2016. Helium and carbon isotopes in the hot springs of Changbaishan volcano, northeastern China: A material connection between Changbaishan volcano and the West Pacific plate? Journal of Volcanology \& Geothermal Research, 327: 398-406.

Wernicke, R.S., and Lippolt, H.J., 1997. (U+Th)-He evidence of Jurassic continuous hydrothermal activity in the Schwarzwald basement, Germany. Chemical Geology, 138(3): 273-285.

Wolf, R.A., Farley, K.A, and Silver, L.T., 1996. Helium diffusion and low-temperaturethermochronometry of apatite.Geochimica Et Cosmochimica Acta, 60: 4231-4240.

Wolf. R.A., Farley, K.A., and Kass, D.M., 1998. Modeling of the temperature sensitivity of the apatite (U-Th)/He thermochronometer. Chemical Geology, 148: 105-114.

Wolff, R., Dunkl, I., Kempe, U., Stockli, D., Wiedenbeck, M., and Eynatten, H.V., 2016. Variable Helium diffusion characteristics in fluorite. Geochimica et Cosmochimica Acta 188: 21-34.

Yang, K., Liu, S.W., Li, Q.G., Wang, Z.Q., Han, Y.G., Wu, F.H., and Zhang, F., 2009. LA-ICP-MS zircon U-Pb geochronology and geological significance of Zhashuigranitoids and Dongjiangkou granitoids from Qinling, Central China. Acta Scientiarum Naturalium Universitatis Pekinesis 45: 841-847.

Yakutseni, V. P., 2014. World helium resources and the perspectives of helium industry development. Petroleum Geology Theoretical and Applied Studies, 9: 1-22.

Zartman, R.E., Wasserburg, G.J., and Reynolds, J.H., 1961. Helium, argon, and carbon in some natural gases, Journal of Geophysical Research Atmospheres, 66: 277-306.

Zhang, G.W., Zhang, B.R., Yuan, X.C., and Xiao, Q.H., 2001. Qinling Orogenic Belt and Continental Dynamics. Beijing: Science Press, 1 - 855 (in Chinese with English abstract).

Zhang, X.B., Xu, Y.C., Sun, M.L., Cheng, K.M., Liu, W.H., Li X.F., and Ma L.Y., 2004. Discovery and its geological significance of the mantle- derived $\mathrm{He}$ in the inclusions of the Ordovician oil-bearing reservoir rocks in the Huanghua depression, China. Science China Earth Sciences 47: 23-29.

Zhang, H.Q., Wei, P.S., and Zhang, J.L., 2005. About the origin of natural gas in Weiyuan field: To discuss with academician Dai Jinxing, Natural Gas Industry, 25: 4-7 (in Chinese).

Zhang, Z.Q., Zhang, G.W., Liu, D.Y., Wang, Z.Q., Tan, S.H., and Wang, J.H., 2006. Isotopic Geochoronology and Geochemistry of Ophiolites, Granites and Clastic Sedimentary Rocks in the Qinling-Dabie Orogenic Belt. Beijing: Geological Publishing House (in Chinese).

Zhang, J., Yang, W., Yi, H.H., Xie. W.R., Zeng, F.Y., and Cen, Y.J., 2015.Feasibility of high-helium natural gas exploration in the Presinian strata, the Sichuan Basin. Natural Gas Industry B 2: 88-94 (in Chinese).

Zhang, X., 2015. Accumulation conditions and resource prediction of nature gas and helium gas in Weihe basin (PhD. thesis). Xi'an, Chang'an University (in Chinese with English abstract)

Zhang W., Li Y.H., Wang L., Zhao F.H., Han W., and Song C.G. 2018. The analysis of helium accumulation conditions and prediction of helium resource in Weihe Basin. Natural Gas Geoscience, 29(2): 236-244 (in Chinese with English abstract).

Zhang W., Li Y.H., Zhao F.H., Han W., Li Y., Wang Y.P., Holland G., and Zhou Z. 2019a. Using noble gases to trace groundwater evolution and assess helium accumulation in Weihe Basin, central China. Geochimica et Cosmochimica Acta, 251: 229-246

Zhang W., Li Y.H., Zhao F.H., Han W., Zhou J.L., Holland G., and Zhou Z. 2019b. Quantifying helium and hydrocarbon accumulation process using noble gases in the North Qaidam Basin, China. Chemical Geology, 525: 368-379.

Zhang W. 2019. Accumulation mechanism of helium, a strategic resource, in Guanzhong and North Qaidam Basin (PhD. thesis). Beijing: China University of Mining and Technology, Beijing (in Chinese with English abstract).

Zhu, M, Zhou, R.G., Yin, D.X., Gao, Y.S., Zhang, F.S., Cheng, B.F., Liu, Q., and Luo, X.H., 2003. Stress emission of helium and argon in coal seams. Science in China (Series D), 46: 547-560.

\section{About the first author}

ZHANG Wen, Female, born in 1994 in Linfen City, Shanxi Province; PhD; graduated from China University of Mining and Technology, Beijing; I am now a post-doctor in Institute of Geology, Chinese Academy of Geological Sciences; I am interested in noble gas geochemistry and their applications for modelling the movement of subsurface fluids, such as helium (a kind of strategic resource), groundwater, hydrocarbon and etc. Besides, I also do research on low-temperature thermochronology, including U-Th-He and Ar-Ar dating. Email: wenzhangen@outlook.com. 


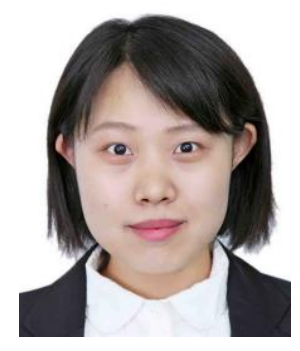

\section{About the Corresponding author}

LI Yuhong, Male, born in 1968 in Yan'an City, Shaanxi Province; PhD; graduated from Institute of Geology and Geophysics, Chinese Academy of Sciences; Senior engineer (professorship) of Xi'an Center, China Geological Survey. He is interested in the study on unconventional oil and gas exploration, helium accumulation, and noble gases geochemistry. E-mail: lyuhong@mail.cgs.gov.cn.

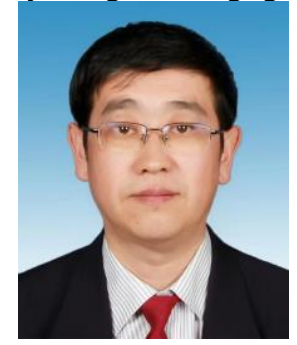

